\title{
Job Satisfaction and Organizational Well-being Evalued through Expectancies and Perceptions
}

\author{
Claudio Palumbo \\ Department of Clinical and Experimental Medicine University of Parma - Italy \\ *Corresponding Author: claudio.palumbo@unipr.it
}

Copyright (c) 2013 Horizon Research Publishing All rights reserved.

\begin{abstract}
Generally it is required a single answer regarding the perceived satisfaction on different aspects of the work and organizational life. The use of questionnaires 'Expectations and Perceptions' bring out the information most properly and credibly by the difference between the expectation base of each one and subsequent evaluation of the actual reality in work place.
\end{abstract}

Keywords Expectations, Perceptions, Job Satisfaction, Organizational Well-being

\section{Introduction}

Requiring a single answer regarding the perceived satisfaction on the different aspects of the work and organizational life, you are likely to flatten the personal assessments and still provide a partial data, as it does not allow to detect the personal expectation, ie the fundamental starting point from which moves each subject interviewed in considering own judgments. The use of questionnaires expectations and perceptions bring out the information most properly and credibly by the difference between the expectation base of each one and subsequent evaluation of the actual reality in work place: in this case, the lack of job satisfaction and organizational well-being are given by the negative difference between higher expectations and own perceptions (Palumbo, 2010b; Zeithaml, Berry, Parasuruman, 1991).

\section{Methodology}

The survey refer to the ratio between the expectations and perceptions about 'job satisfaction' (Herzberg, 1959) and 'organizational well-being' (Avallone, Paplomatas, Marchetti, 2003; Avallone, Paplomatas, 2005). The calculations are related to:

- The average of each item of the questionnaires;

- The differences between expectations and perceptions;

- The average of mean deviation;
- The difference in the plus and minus of each deviation from the average.

The possible intersections of the data can bring out the underlying aspects of work experiences as reasons for satisfaction or dissatisfaction.

This can further direct the Organization to recognize and deal with certain critical issues and highlight strengths, designing and implementing courses of action which lead to a continuous improvement of organizational well-being (Palumbo, 2010b).

The specific issue of this study was the evaluation of stress at work correlation. This evaluation includes, the Organization, of an Italian Municipal Authority, called for an assessment of organizational well-being. The research was carried out on a group of 91 employees aged between 28/59 (42 men and 49 women). The evaluation involved the entire staff of the Organization, by submitting the questionnaires on the expectations and the next day the questionnaires on perceptions. This is to reduce the memory of the answers to the questionnaires on expectations, thus limiting the possible influencing the responses related to perceptions and at the same time without spend a lot of time between the first and second administration. The questionnaires consists of:

- 16 questions on the expectations and perceptions of job satisfaction (the questions are respectively: 'What is more important for you in a job?' and 'How much is satisfied with his work?'), with response scale from 1 (less important) to 10 (most important) (Palumbo, 2006; 2010b);

- 27 questions on the expectations and perceptions of organizational well-being (the questions are respectively: 'How important is for you that in an work organization:' and 'In the organization where you work:'), with response scale from 1 (less important) to 10 (most important)

(Palumbo, 2006; 2010b).

Choosing the 10-point scale is suggested by studies on the expectations / perceptions of Quality (Zeithaml, Berry,

Parasuruman,1991). The scale reminds respondents assessments of the Italian school and is particularly suitable for those not user to answer research questionnaires and self-assessments. 


\section{Results}

Table 1 shows the differences between expectations and perceptions of items on the job satisfaction; negative signs highlight the prevalence of expectations on perceptions, the items and values are, ie: most marked critical issues.

Table 1. Differences between expectations and perceptions on the job satisfaction

\begin{tabular}{|c|c|}
\hline ITEMS & DIFFERENCES \\
\hline 1) Relations with colleagues subordinate & $-1,63$ \\
\hline 2) The level of responsibilities & $-0,24$ \\
\hline 3) Organization strategies & $-0,44$ \\
\hline 4) The prestige of the organization & $-0,23$ \\
\hline 5) The phisical conditions of work & $-0,28$ \\
\hline 6) The contents of work & $-0,05$ \\
\hline 7) The skill of superiors & $-0,66$ \\
\hline 8) Relations with co-workers at the same position & $-0,83$ \\
\hline 9) Achieving of results & $-0,61$ \\
\hline 10) Warranty workplace & 0,54 \\
\hline 11) The opportunity to professional growth & $-0,88$ \\
\hline 12) The relationship with higher & $-1,01$ \\
\hline 13) Recognize the merits & $-1,01$ \\
\hline 14) The level of salary & $-0,25$ \\
\hline 15) Career opportunities & $-0,35$ \\
\hline 16) Ways by which we work & $-0,73$ \\
\hline AVERAGE OF MEAN DEVIATION & $-0,64$ \\
\hline
\end{tabular}

The most problematic areas, they are above of average of mean deviation, refer to the order:

1) Relations with colleagues subordinate

2) The relationship with higher and Recognize the merits

3) The opportunity to professional growth

4) Relations with co-workers at the same position

5) Methods of works

6) The skill of superiors

Table 2 shows the differences between expectations and perceptions of the items related to the organizational well-being; the negative signs highlight the prevalence of expectations on perceptions, the items and values shown in bold exceeds the mean deviation average, ie: most marked critical issues. In addition, it should be emphasized positivity of the difference on the 'Perception of the social utility of own work since perceptions are higher than expectations.
Table 2. Differences between expectations and perceptions of the organizational well-being

\begin{tabular}{|c|c|}
\hline ITEMS & DIFF. \\
\hline 1) Arrange for a hygienic work environment & $-0,92$ \\
\hline $\begin{array}{l}\text { 2) Arrange for a comfortable working environment with } \\
\text { friendly atmosphere }\end{array}$ & $-0,46$ \\
\hline 3) Clear and explicit targets & $-1,12$ \\
\hline $\begin{array}{l}\text { 4) What you decide to do is consistent with what is done } \\
\text { operationally }\end{array}$ & $-0,52$ \\
\hline $\begin{array}{l}\text { 5) Recognize and enhance the skills and contributions of } \\
\text { individual staff }\end{array}$ & $-1,25$ \\
\hline 6) Promote the updating and sharing of knowledge & $-1,00$ \\
\hline 7) Consider the demands and proposals of employees & $-0,87$ \\
\hline 8) Make available information regarding the work & $-0,81$ \\
\hline $\begin{array}{l}\text { 9) Manage conflicts between people within acceptable levels } \\
\text { of coexistence }\end{array}$ & $-0,97$ \\
\hline $\begin{array}{l}\text { 10) Stimulate open communication and collaboration } \\
\text { relationships }\end{array}$ & $-0,83$ \\
\hline 11) Prompt in decisions and flowing on an operational level & $-0,37$ \\
\hline 12) Facing problems with the intent of overcoming them & $-1,06$ \\
\hline 13) Proceed towards common goals & $-0,60$ \\
\hline 14) Must be clearly defined the systems of staff evaluation & $-0,71$ \\
\hline 15) Must be clearly defined economic incentives & $-6,66$ \\
\hline 16) Must be clearly defined career opportunities & $-0,50$ \\
\hline 17) Must be clearly defined the responsibilities & $-0,52$ \\
\hline 18) Make tolerable the overall level of phisical effort & $-0,88$ \\
\hline 19) Make tolerable the overall level of mental effort & $-6,08$ \\
\hline 20) Perception of the social utility of own work & 1,28 \\
\hline $\begin{array}{l}\text { 21) Perceive own work contributes to the achievement of } \\
\text { results common to the whole organization }\end{array}$ & $-0,75$ \\
\hline $\begin{array}{l}\text { 22) Safety and health protection are cultural and personal } \\
\text { assets of the organization }\end{array}$ & $-1,29$ \\
\hline $\begin{array}{l}\text { 23) Comply with the law in order to prevent accidents and } \\
\text { occupational hazards }\end{array}$ & $-0,87$ \\
\hline 24) Sustainability of the tasks of individual workers & $-0,99$ \\
\hline 25) Sustainability of the tasks of working groups & $-0,62$ \\
\hline 26) Openness to the external environment & $-0,62$ \\
\hline 27) Openness to cultural and technological innovation & $-1,04$ \\
\hline AVERAGE OF MEAN DEVIATION & $-0,79$ \\
\hline
\end{tabular}

The most problematic areas, they are above of average of mean deviation, refer to the order:

1) Legibility of economic incentives

2) Tolerance of physical effort

3) Safety and health protection are cultural and personal assets of the organization

4) Recognize and enhance the skills and contributions of individual staff

5) Clear and explicit targets

6) Face and overcome problems 
7) Openness to cultural and technological innovation

8) Promote updating and sharing of knowledges

9) Sustainability of the tasks of individual workers

10) Manage conflicts between people within acceptable levels of coexistence

11) Arrange for a hygienic work environment

12) Tolerance of physical effort

13) Consider the demands and proposals of employees

14) Compliance with legal obligations to prevent accidents and occupational hazards

15) Stimulate open communication and collaboration relationships

16) Make available information regarding the work.

The frequencies of answers in the scales of items on perceptions of the Job Satisfaction and Organizational Well-being are not concentrated on higher side. In this regard, were placed two tables of frequencies of answers to the items (Table 3 and 4).

Tables 5 and 6 shows significant correlations between the items of the questionnaires referring respectively to expectations (Table 5) and perceptions (Table 6).

Table 3. Frequency of the responses to the items of perceptions on job satisfaction (in bold the highest value of the item: values prevailing 5 and 8 )

\begin{tabular}{|c|c|c|c|c|c|c|c|c|c|c|}
\hline ITEM & $\mathbf{1}$ & $\mathbf{2}$ & $\mathbf{3}$ & $\mathbf{4}$ & $\mathbf{5}$ & $\mathbf{6}$ & $\mathbf{7}$ & $\mathbf{8}$ & $\mathbf{9}$ & $\mathbf{1 0}$ \\
\hline 1) Relations with colleagues subordinate & $\mathbf{2 1}$ & 0 & 1 & 0 & 6 & 7 & 7 & 10 & 4 & 4 \\
\hline 2) The level of responsibilities & 1 & 2 & 4 & 4 & 10 & 14 & 18 & $\mathbf{2 3}$ & 11 & 4 \\
\hline 3) Organization strategies & 17 & 8 & 10 & 13 & $\mathbf{2 1}$ & 13 & 3 & 3 & 3 & 0 \\
\hline 4) The prestige of the organization & 10 & 10 & 10 & 10 & 14 & $\mathbf{2 4}$ & 7 & 5 & 1 & 0 \\
\hline 5) The phisical conditions of work & 1 & 1 & 2 & 3 & 10 & $\mathbf{2 5}$ & 19 & 23 & 5 & 2 \\
\hline 6) The contents of work & 2 & 2 & 2 & 3 & 8 & 14 & 18 & $\mathbf{2 5}$ & 13 & 4 \\
\hline 7) The skill of superiors & 3 & 3 & 3 & 5 & 14 & 15 & $\mathbf{1 8}$ & 14 & 9 & 7 \\
\hline 9) Achieving of results & 5 & 1 & 1 & 3 & 8 & 13 & 15 & $\mathbf{2 4}$ & 12 & 9 \\
\hline 10) Warranty workplace & 3 & 2 & 2 & 3 & 10 & 14 & 20 & $\mathbf{3 1}$ & 5 & 1 \\
\hline 8) Relations with co-workers at the same position & 3 & 1 & 1 & 1 & 2 & 4 & 15 & $\mathbf{2 5}$ & 17 & 22 \\
\hline 11) The opportunity to professional growth & 12 & 4 & 9 & 10 & $\mathbf{1 4}$ & 13 & 13 & 10 & 3 & 3 \\
\hline 12) The relationship with higher & 4 & 4 & 5 & 5 & 11 & $\mathbf{1 9}$ & 15 & 15 & 7 & 6 \\
\hline 13) Recognize the merits & 11 & 6 & 6 & 8 & $\mathbf{1 9}$ & 16 & 13 & 9 & 3 & 0 \\
\hline 14) The level of salary & 9 & 2 & 3 & 12 & 16 & $\mathbf{2 7}$ & 15 & 6 & 1 & 0 \\
\hline 16) Ways by which we work & 6 & 6 & 9 & 10 & $\mathbf{2 0}$ & 17 & 12 & 8 & 3 & 0 \\
\hline
\end{tabular}


Table 4. Frequency of the responses to the items on the perceptions of organizational well-being (in bold the highest value of the item: value prevailing 6)

\begin{tabular}{|c|c|c|c|c|c|c|c|c|c|c|}
\hline ITEM & 1 & 2 & 3 & 4 & 5 & 6 & 7 & 8 & 9 & 10 \\
\hline 1) Arrange for a hygienic work environment & 3 & 4 & 4 & 4 & 6 & 18 & 24 & 13 & 10 & 5 \\
\hline 2) Arrange for a comfortable working environment with friendly atmosphere & 3 & 3 & 5 & 6 & 11 & 19 & 21 & 16 & 7 & 0 \\
\hline 3) Clear and explicit targets & 6 & 7 & 9 & 10 & 15 & 17 & 14 & 8 & 4 & 1 \\
\hline 4) What you decide to do is consistent with what is done operationally & 4 & 5 & 9 & 10 & 21 & 20 & 11 & 9 & 2 & 0 \\
\hline 5) Recognize and enhance the skills and contributions of individual staff & 13 & 9 & 9 & 9 & 21 & 16 & 7 & 5 & 2 & 0 \\
\hline 6) Promote the updating and sharing of knowledge & 7 & 7 & 8 & 10 & 20 & 18 & 10 & 8 & 3 & 0 \\
\hline 7) Consider the demands and proposals of employees & 9 & 9 & 9 & 10 & 22 & 18 & 10 & 3 & 1 & 0 \\
\hline 8) Make available information regarding the work & 2 & 4 & 9 & 11 & 13 & 31 & 18 & 2 & 1 & 0 \\
\hline 9) Manage conflicts between people within acceptable levels of coexistence & 3 & 4 & 5 & 6 & 10 & 20 & 22 & 14 & 6 & 1 \\
\hline 10) Stimulate open communication and collaboration relationships & 5 & 8 & 9 & 9 & 25 & 18 & 10 & 3 & 3 & 1 \\
\hline 11) Prompt in decisions and flowing on an operational level & 4 & 7 & 9 & 10 & 20 & 16 & 16 & 7 & 2 & 0 \\
\hline 12) Facing problems with the intent of overcoming them & 6 & 6 & 8 & 13 & 13 & 19 & 11 & 8 & 7 & 0 \\
\hline 13) Proceed towards common goals & 6 & 8 & 10 & 11 & 16 & 19 & 11 & 6 & 4 & 0 \\
\hline 14) Must be clearly defined the systems of staff evaluation & 7 & 9 & 10 & 11 & 13 & 22 & 12 & 4 & 2 & 1 \\
\hline 15) Must be clearly defined economic incentives & 16 & 6 & 9 & 12 & 19 & 18 & 8 & 1 & 1 & 1 \\
\hline 16) Must be clearly defined career opportunities & 21 & 6 & 11 & 12 & 19 & 15 & 7 & 0 & 0 & 0 \\
\hline 17) Must be clearly defined the responsibilities & 9 & 9 & 9 & 10 & 17 & 19 & 10 & 6 & 1 & 1 \\
\hline 18) Make tolerable the overall level of phisical effort & 0 & 4 & 5 & 5 & 6 & 20 & 17 & 17 & 12 & 5 \\
\hline 19) Make tolerable the overall level of mental effort & 3 & 3 & 11 & 5 & 6 & 25 & 15 & 13 & 8 & 2 \\
\hline 20) Perception of the social utility of own work & 4 & 5 & 5 & 5 & 6 & 18 & 17 & 15 & 13 & 3 \\
\hline $\begin{array}{l}\text { 21) Perceive own work contributes to the achievement of results common to the } \\
\text { whole organization }\end{array}$ & 4 & 6 & 6 & 6 & 10 & 24 & 13 & 11 & 10 & 1 \\
\hline $\begin{array}{l}\text { 22) Safety and health protection are cultural and personal assets of the } \\
\text { organization }\end{array}$ & 2 & 3 & 4 & 5 & 7 & 14 & 17 & 22 & 15 & 2 \\
\hline 23) Comply with the law in order to prevent accidents and occupational hazards & 2 & 2 & 3 & 4 & 4 & 10 & 20 & 22 & 19 & 5 \\
\hline 24) Sustainability of the tasks of individual workers & 5 & 5 & 5 & 3 & 10 & 26 & 18 & 13 & 6 & 0 \\
\hline 25) Sustainability of the tasks of working groups & 4 & 4 & 5 & 5 & 16 & 23 & 16 & 14 & 4 & 0 \\
\hline 26) Openness to the external environment & 2 & 3 & 3 & 4 & 9 & 22 & 18 & 17 & 11 & 2 \\
\hline 27) Openness to cultural and technological innovation & 1 & 4 & 4 & 4 & 5 & 22 & 20 & 19 & 11 & 1 \\
\hline
\end{tabular}


Table 5. Correlations between the expectations (in bold correlations previously mentioned in the text)

\begin{tabular}{|c|c|c|c|c|c|c|c|c|c|c|c|c|c|c|c|c|}
\hline & $\begin{array}{c}\text { Rel. } \\
\text { coll.sub. }\end{array}$ & $\begin{array}{l}\text { Level } \\
\text { resp. }\end{array}$ & $\begin{array}{l}\text { Organiz. } \\
\text { strategies }\end{array}$ & $\begin{array}{l}\text { Prestige } \\
\text { organiz. }\end{array}$ & $\begin{array}{c}\text { Phisical } \\
\text { cond.work }\end{array}$ & $\begin{array}{c}\text { Contents } \\
\text { of work }\end{array}$ & $\begin{array}{c}\text { Skill of } \\
\text { superiors }\end{array}$ & $\begin{array}{c}\text { Rel. } \\
\text { co-workers }\end{array}$ & $\begin{array}{l}\text { Achie. } \\
\text { results }\end{array}$ & $\begin{array}{c}\text { Warr. } \\
\text { Workpl. }\end{array}$ & $\begin{array}{l}\text { Profes. } \\
\text { growth }\end{array}$ & $\begin{array}{c}\text { Rel. } \\
\text { higher }\end{array}$ & $\begin{array}{c}\text { Recogn. } \\
\text { merits }\end{array}$ & $\begin{array}{l}\text { Level } \\
\text { salary }\end{array}$ & $\begin{array}{l}\text { Career } \\
\text { opport. }\end{array}$ & $\begin{array}{l}\text { Ways } \\
\text { work }\end{array}$ \\
\hline $\begin{array}{l}\text { Arrange for a } \\
\text { hygienic work } \\
\text { environment }\end{array}$ & & & & & & & & & $\begin{array}{l}0,213 \\
*\end{array}$ & & $\begin{array}{l}0,273 \\
*\end{array}$ & & & & & \\
\hline $\begin{array}{c}\text { Arrange for a } \\
\text { comfortable working } \\
\text { environ. }\end{array}$ & & & & & & & & $\begin{array}{c}0,271 \\
* *\end{array}$ & $\begin{array}{c}0,269 \\
*\end{array}$ & & $\begin{array}{l}0,313 \\
* *\end{array}$ & & & & & \\
\hline $\begin{array}{c}\text { Clear and explicit } \\
\text { targets }\end{array}$ & & $\begin{array}{c}0,352 \\
* * \\
\end{array}$ & $\begin{array}{c}0,250 \\
*\end{array}$ & & & & & & $\begin{array}{c}0,249 \\
*\end{array}$ & & $\begin{array}{c}0,362 \\
* *\end{array}$ & & & & & \\
\hline $\begin{array}{l}\text { Decisions consistent } \\
\text { with the operational } \\
\text { work }\end{array}$ & & & & & & & $\begin{array}{l}0,237 \\
*\end{array}$ & & & & $\begin{array}{c}0,269 \\
*\end{array}$ & & & & & \\
\hline \multicolumn{17}{|l|}{$\begin{array}{c}\text { Recognize enhance } \\
\text { skills contributions } \\
\text { individual } \\
\end{array}$} \\
\hline $\begin{array}{l}\text { Promote updating } \\
\text { and sharing } \\
\text { of knowledges }\end{array}$ & & & & & & & $\begin{array}{c}0,207 \\
*\end{array}$ & $\begin{array}{c}0,225 \\
*\end{array}$ & & & $\begin{array}{c}0,224 \\
*\end{array}$ & & $\begin{array}{l}0,219 \\
*\end{array}$ & & & $\begin{array}{l}0,245 \\
* *\end{array}$ \\
\hline $\begin{array}{c}\text { Consider demands } \\
\text { and proposals of } \\
\text { employees }\end{array}$ & & & & & & & & & $\begin{array}{l}0,216 \\
*\end{array}$ & & $\begin{array}{c}0,215 \\
*\end{array}$ & & & & & $\begin{array}{c}0,221 \\
*\end{array}$ \\
\hline $\begin{array}{c}\text { Available } \\
\text { information } \\
\text { regarding the work }\end{array}$ & & & & & & & & & $\begin{array}{c}0,265 \\
*\end{array}$ & & & & & & & \\
\hline $\begin{array}{l}\text { Conflicts within } \\
\text { acceptable levels of } \\
\text { coexistence }\end{array}$ & $\begin{array}{l}0,207 \\
*\end{array}$ & & $\begin{array}{c}0,212 \\
*\end{array}$ & & & & & & & & & & & & & \\
\hline \multicolumn{17}{|l|}{$\begin{array}{l}\text { Open communic. } \\
\text { collaborat.relation. }\end{array}$} \\
\hline $\begin{array}{l}\text { Prompt decisions and } \\
\text { flowing on an } \\
\text { operational level }\end{array}$ & & & $\begin{array}{c}0,250 \\
*\end{array}$ & & & & & & & & $\begin{array}{c}0,388 \\
* *\end{array}$ & & & & $\begin{array}{c}0,212 \\
*\end{array}$ & \\
\hline $\begin{array}{l}\text { Facing overcome } \\
\text { problems }\end{array}$ & & & $\begin{array}{c}0,221 \\
*\end{array}$ & & & & & & $\begin{array}{c}0,296 \\
*\end{array}$ & & $\begin{array}{c}0,275 \\
* *\end{array}$ & & & & & \\
\hline $\begin{array}{l}\text { Proceed towards } \\
\text { common goals }\end{array}$ & & $\begin{array}{c}0,236 \\
*\end{array}$ & & & & & & & & & $\begin{array}{c}0,280 \\
* *\end{array}$ & & & & & \\
\hline
\end{tabular}




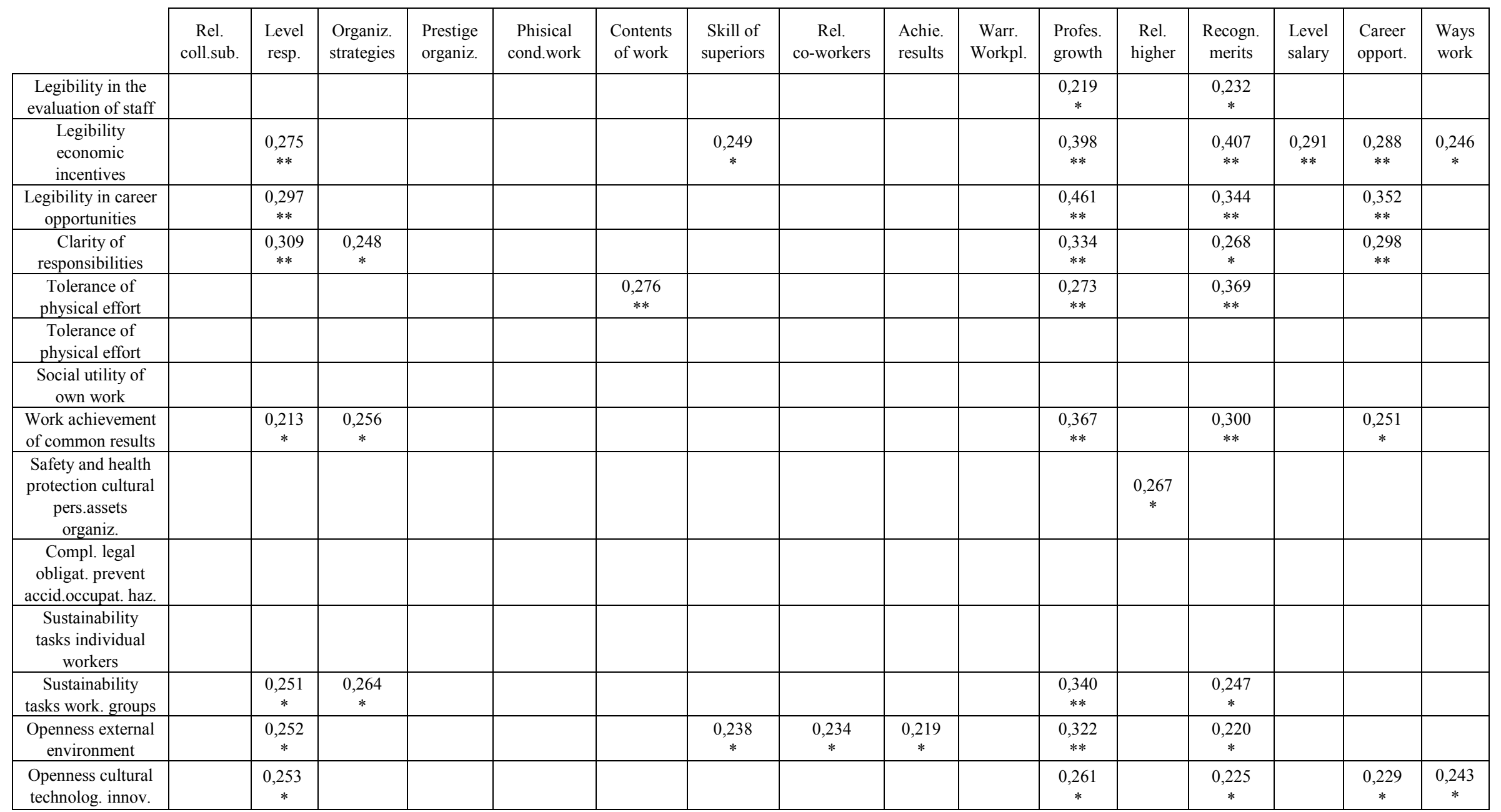

$* \mathrm{p}<0,05$

** $\mathrm{p}<0,01$ 
Table 6. Correlations between the perceptions (in bold correlations previously mentioned in the text)

\begin{tabular}{|c|c|c|c|c|c|c|c|c|c|c|c|c|c|c|c|c|}
\hline & $\begin{array}{l}\text { Rel. } \\
\text { coll.sub. }\end{array}$ & $\begin{array}{l}\text { Level } \\
\text { resp. }\end{array}$ & $\begin{array}{l}\text { Organiz. } \\
\text { strategies }\end{array}$ & $\begin{array}{l}\text { Prestige } \\
\text { organiz. }\end{array}$ & $\begin{array}{l}\text { Phisical } \\
\text { cond.work }\end{array}$ & $\begin{array}{l}\text { Contents } \\
\text { of work }\end{array}$ & $\begin{array}{l}\text { Skill of } \\
\text { superiors }\end{array}$ & $\begin{array}{c}\text { Rel. } \\
\text { co-workers }\end{array}$ & $\begin{array}{l}\text { Achie. } \\
\text { results }\end{array}$ & $\begin{array}{l}\text { Warr. } \\
\text { Workpl. }\end{array}$ & $\begin{array}{l}\text { Profes. } \\
\text { growth }\end{array}$ & $\begin{array}{l}\text { Rel. } \\
\text { higher }\end{array}$ & $\begin{array}{l}\text { Recogn. } \\
\text { merits }\end{array}$ & $\begin{array}{l}\text { Level } \\
\text { salary }\end{array}$ & $\begin{array}{l}\text { Career } \\
\text { opport. }\end{array}$ & $\begin{array}{l}\text { Ways } \\
\text { work }\end{array}$ \\
\hline $\begin{array}{c}\text { Arrange for a } \\
\text { hygienic work } \\
\text { environment }\end{array}$ & & & & & & & & & & & & & & & & \\
\hline $\begin{array}{c}\text { Arrange for a } \\
\text { comfortable } \\
\text { working environ. }\end{array}$ & & & & & & & & & & & & & & & & \\
\hline $\begin{array}{c}\text { Clear and explicit } \\
\text { targets }\end{array}$ & & & & & $\begin{array}{c}0,214 \\
*\end{array}$ & $\begin{array}{c}0,222 \\
*\end{array}$ & & & & & & & & & & \\
\hline $\begin{array}{c}\text { Decisions } \\
\text { consistent with the } \\
\text { operational work }\end{array}$ & & & & $\begin{array}{l}0,247 \\
*\end{array}$ & $\begin{array}{c}0,253 \\
*\end{array}$ & $\begin{array}{l}0226 \\
*\end{array}$ & & & & & & $\begin{array}{l}0,249 \\
*\end{array}$ & $\begin{array}{c}0,317 \\
* *\end{array}$ & & & $\begin{array}{c}0,228 \\
*\end{array}$ \\
\hline $\begin{array}{l}\text { Recognize enhance } \\
\text { skills contributions } \\
\text { individual }\end{array}$ & & & & & & $\begin{array}{c}0,211 \\
*\end{array}$ & & & & & & & & & & $\begin{array}{c}0,215 \\
*\end{array}$ \\
\hline $\begin{array}{l}\text { Promote updating } \\
\text { and sharing } \\
\text { of knowledges }\end{array}$ & & & & & & & & & & & & & & & & \\
\hline $\begin{array}{l}\text { Consider demands } \\
\text { and proposals of } \\
\text { employees }\end{array}$ & & & & & & & & & & & & & & & & \\
\hline $\begin{array}{c}\text { Available } \\
\text { information } \\
\text { regarding the work }\end{array}$ & & & & & & & & & & & & & & & & \\
\hline $\begin{array}{c}\text { Conflicts within } \\
\text { acceptable levels of } \\
\text { coexistence }\end{array}$ & & & & & & & & & & & & & & & & \\
\hline $\begin{array}{l}\text { Open communic. } \\
\text { collaborat.relation. }\end{array}$ & & & & & & & & & & & & & & & & \\
\hline $\begin{array}{l}\text { Prompt decisions } \\
\text { and flowing on an } \\
\text { operational level }\end{array}$ & & & & & & & & & & & & & & & & \\
\hline $\begin{array}{l}\text { Facing overcome } \\
\text { problems }\end{array}$ & & & & & & & & & & & & & & & & $\begin{array}{c}0,231 \\
*\end{array}$ \\
\hline $\begin{array}{c}\text { Proceed towards } \\
\text { common goals }\end{array}$ & & & & & $\begin{array}{c}0,213 \\
*\end{array}$ & & & & & & & & & & & $\begin{array}{l}0,220 \\
*\end{array}$ \\
\hline
\end{tabular}




\begin{tabular}{|c|c|c|c|c|c|c|c|c|c|c|c|c|c|c|c|c|}
\hline & $\begin{array}{c}\text { Rel. } \\
\text { coll.sub. }\end{array}$ & $\begin{array}{l}\text { Level } \\
\text { resp. }\end{array}$ & $\begin{array}{l}\text { Organiz. } \\
\text { strategies }\end{array}$ & $\begin{array}{l}\text { Prestige } \\
\text { organiz. }\end{array}$ & $\begin{array}{l}\text { Phisical } \\
\text { cond.work }\end{array}$ & $\begin{array}{l}\text { Contents } \\
\text { of work }\end{array}$ & $\begin{array}{c}\text { Skill of } \\
\text { superiors }\end{array}$ & $\begin{array}{c}\text { Rel. } \\
\text { co-workers }\end{array}$ & $\begin{array}{l}\text { Achie. } \\
\text { results }\end{array}$ & $\begin{array}{l}\text { Warr. } \\
\text { Workpl. }\end{array}$ & $\begin{array}{l}\text { Profes. } \\
\text { growth }\end{array}$ & $\begin{array}{l}\text { Rel. } \\
\text { higher }\end{array}$ & $\begin{array}{l}\text { Recogn. } \\
\text { merits }\end{array}$ & $\begin{array}{l}\text { Level } \\
\text { salary }\end{array}$ & $\begin{array}{l}\text { Career } \\
\text { opport. }\end{array}$ & $\begin{array}{l}\text { Ways } \\
\text { work }\end{array}$ \\
\hline $\begin{array}{l}\text { Legibility in the } \\
\text { evaluation of staff }\end{array}$ & & & & & $\begin{array}{c}0,234 \\
*\end{array}$ & & $\begin{array}{c}-0,236 \\
*\end{array}$ & & & & & & & & & \\
\hline $\begin{array}{l}\text { Legibility } \\
\text { economic } \\
\text { incentives }\end{array}$ & & & & & & & & & & & & & & & & \\
\hline $\begin{array}{c}\text { Legibility in career } \\
\text { opportunities }\end{array}$ & & & & & & & & & & & & & & & & \\
\hline $\begin{array}{c}\text { Clarity of } \\
\text { responsibilities }\end{array}$ & & & & & & & & & & & & & & & & \\
\hline $\begin{array}{c}\text { Tolerance of } \\
\text { physical effort }\end{array}$ & & & & & & & & & & & & & & & & \\
\hline $\begin{array}{c}\text { Tolerance of } \\
\text { physical effort }\end{array}$ & & & & & & & & & & & & & & & & \\
\hline $\begin{array}{c}\text { Social utility of } \\
\text { own work }\end{array}$ & & & & & & & & & & & & & & & & \\
\hline $\begin{array}{l}\text { Work achievement } \\
\text { of common results }\end{array}$ & & & & & & & & & & $\begin{array}{c}0,215 \\
*\end{array}$ & & & & & & \\
\hline $\begin{array}{c}\text { Safety and health } \\
\text { protection cultural } \\
\text { pers.assets organiz. }\end{array}$ & & & & & $\begin{array}{c}0,254 \\
*\end{array}$ & & & & & & $\begin{array}{c}0,237 \\
*\end{array}$ & $\begin{array}{l}0,250 \\
*\end{array}$ & $\begin{array}{c}0,260 \\
*\end{array}$ & & & \\
\hline $\begin{array}{c}\text { Compl. legal } \\
\text { obligat. prevent } \\
\text { accid.occupat. haz. }\end{array}$ & & & & & & & & & & $\begin{array}{c}0,249 \\
*\end{array}$ & & & & & & $\begin{array}{l}0,242 \\
*\end{array}$ \\
\hline $\begin{array}{l}\text { Sustainability tasks } \\
\text { individual workers }\end{array}$ & & & & & & & & & & & & & $\begin{array}{c}0,221 \\
*\end{array}$ & & & $\begin{array}{c}0,347 \\
* * \\
\end{array}$ \\
\hline $\begin{array}{c}\text { Sustainability tasks } \\
\text { work. groups }\end{array}$ & & & & & & & & & & & & & & & & $\begin{array}{c}0,306 \\
* * \\
\end{array}$ \\
\hline $\begin{array}{c}\text { Openness external } \\
\text { environment }\end{array}$ & & & & & $\begin{array}{c}0,266 \\
*\end{array}$ & & & & & & & & $\begin{array}{c}0,222 \\
*\end{array}$ & & & $\begin{array}{c}0,215 \\
* \\
\end{array}$ \\
\hline $\begin{array}{l}\text { Openness cultural } \\
\text { technolog. innov. }\end{array}$ & & $\begin{array}{c}0,219 \\
*\end{array}$ & & & & & $\begin{array}{l}0,228 \\
*\end{array}$ & & & & & & $\begin{array}{l}0,297 \\
* *\end{array}$ & & & $\begin{array}{c}0,224 \\
*\end{array}$ \\
\hline
\end{tabular}

$* \mathrm{p}<0,05$

$* * \mathrm{p}<0,01$ 
In the case of expectations, the item of major importance is the Opportunities for professional growth that has 14 correlations and an item is placed in the fourth place on the list of highest negative differences between expectations and perceptions of job satisfaction. Some of these correlations are so high as logically expected, such as: Legibility in career opportunities.

Even if of lesser importance, the correlation with the Legibility of economic incentives assumes a basic value as the latter appears to have the highest negative gap between the expectations and perceptions of organizational well-being. Less important are the correlations with the Clear and explicit targets and Facing and overcome problems, fifth and sixth respectively in the order of the differences between expectations and perceptions just mentioned. Statistically speaking, among other significant correlations, the higher is Prompt in decisions and flowing on an operational level.

The second item of greatest importance is the Recognition of the merits, which has 10 correlations and an item is placed on the second place on the list of highest negative deviations between expectations and perceptions of job satisfaction. The highest correlation of these correlations is also a strong intrinsic logic as it is with the Legibility of economic incentives (the importance of which I refer to the above). The second correlation in order of relevance is the Tolerance of physical effort: higher the attention to recognition of merits the more you can rely on the tolerability of physical effort by staff. Makes the following obvious correlation with Legibility in career Opportunities, but as mentioned above, we consider only the statistical value because it is below the average of the negative differences between expectations and perceptions of organizational well-being. Then we find the correlation with Work for the achievement of common results. Again, this is below the negative differences, however it is interesting to report it since it is also present with a similar value in relations with the Opportunities for professional growth, to confirm an interest of the staff for their work, which contributes to the achievement of common matches to the entire Organization (in this way, although less, we can also play the correlation with Strategies organization, which should aim to perceive that: 'own work contributes to the achievement of common results of the entire Organization').

Between the correlations of lower statistical value, we list: Openness to cultural and technological innovation, Promote updating and sharing of knowledges (also seen in the correlation with the Opportunities for professional growth), respectively the seventh and eighth of negative differences between expectations and perceptions of organizational well-being.

Finally, just for the inevitable coherence of meaning, we have the correlation with the Legibility of staff evaluation systems, which is present, although with less statistical value in the correlation with the Opportunities for professional growth.

The third item of major importance is the Level of responsibility that enumerates 9 correlations, the highest of these is with the Clear and explicit targets, follow the logical relations with Clarity of responsibilities and Clarity in career opportunities, and return the important correlation with the Clarity of economic incentives, as pointed out in the preceding two items. Interesting, even if the statistical value of the lowest correlations are with the Proceed towards the common goals (also seen in the correlation with Opportunities for professional growth) and Work for the achievement of common results; the latter, as well as having a meaning consistent with each other, recall and confirm as soon as the interest of the staff claimed that their work contributes to the achievement of common results of the entire Organization.

In the case of perception, the correlations are much lower and less as statistical significance. The item of greatest relevance is the Ways by which we work, with 9 correlations. This is an item placed in sixth place on the list of highest negative differences between expectations and perceptions of job satisfaction.

The highest correlations are found with the Sustainability of the tasks of individual workers (ninth of higher negative differences in organizational well-being) and the Sustainability of the tasks of working groups. We can interpret these correlations in the sense of a generalized everyday perception: in the Organization 'as you work' is measured by the ability to withstand work tasks either individually or in a workgroup.

Other correlations can provide more information on which issues the staff addressed the daily attention to evaluate personal work methods and the workplace in order of statistical significance so to obtain (the position in the ranking of highest negative differences between expectations and perceptions of organizational well-being): Compliance with legal obligations to prevent accidents and occupational hazards (14th), Face and overcome problems (6th), Decisions consistent with the operational work, Openness to cultural and technological innovation (7th), Move towards common goals, Openness to the external environment, Recognize and enhance the skills and contributions of individual staff (4th).

Further, must be noted two more interesting correlations inside of perceptions. The first, of a high statistical significance, is between Recognition of the merits and Consistent decisions with what gets operationally. The second is the only case of a negative correlation and it is between Skills of superiors (item placed in sixth place on the list of highest negative differences between expectations and perceptions of job satisfaction) and Legibility in the evaluation of staff; a sign of discomfort with the fact that these two factors are not equal distance but even go in opposite directions.

\section{Conclusion}

From the set of results, the critical issues that the 
Organization should face first are:

- Communicative and relational;

- Meritocratic (legibility evaluation systems that would lead to an increase in positive perception of the skills of superiors) recognition and enhancement of skills and professional growth;

- Referring to the working methods that mostly cause mental effort and difficulty keeping assigned duties; - Concerning the legibility of common goals and willingness to face and overcome problems through decisions consistent with the actual effective operation.

All this indicates that the upgrades should go especially in the direction of the interface individual / organization with the help of educational trainings turned to homogeneous groups of work, but also transversal at an organizational level.

In conclusion, we add some indications more specific action-oriented.

- More effective use of the intranet: a forum is always open and managed by one or more directors in rotation;

- Reinforce the group cohesion through:

- The increase in the number of meetings of the working groups and sectors;

- The definition of informal rules possibly clear, precise and to make known to all (the rules can be changed, but there must always be a reason shared and functional in order to solve problems, to avoid the risk of falling into purely manipulative interventions);

- Socialization of the outcomes of its activities;

- The sharing of skills acquired by updates made (in groups or individually) on matters concerning the scope of activity; - The clarification of conflicts (as much as you clarify the intentions in the early stages of an activity, the more the conflict is kept under control);

- A leadership style participative (distinction between the role and function), the self-empowerment that face before submitting their point of view, to solicit the employees to submit their ideas and expectations;

- The tendency of employees to propose a hypothesis of solution while undergoing a problem;

- The exchange of feedback (constructive criticism) individual and collective.

\section{REFERENCES}

[1] Avallone F., Paplomatas A., Marchetti S. (2003). La salute organizzativa (The organizational health). In Quaderni di Psicologia del Lavoro, 10, pp. 111-122.

[2] Avallone F., Paplomatas A. (2005). Salute organizzativa (Organizational health). Milano: Raffaello Cortina Editore.

[3] Palumbo C. (2006). Andare oltre. Idee per lo sviluppo delle competenze trasversali (Going beyond. Ideas for the development of soft skills). Parma: Edizioni Santa Croce.

[4] Palumbo C. (2010a). Andare oltre 2. Ricerche per lo sviluppo delle competenze trasversali (Going beyond 2. Research for the development of soft skills). Parma: Edizioni Santa Croce.

[5] Palumbo C. (2010b). La valutazione dello stress lavoro correlate (The evaluation of stress at work correlation). Parma: Edizioni Santa Croce.

[6] Herzberg F. (1959). The motivation to work. London: Wiley.

[7] Zeithaml V.A., Berry L.L., Parasuruman A. (1991). Servire Qualità (Serve Quality). Milano: McGraw-Hill. 